TITLE:

\title{
Generation of mouse-induced pluripotent stem cells with plasmid vectors.
}

\section{$\operatorname{AUTHOR}(\mathrm{S})$ :}

Okita, Keisuke; Hong, Hyenjong; Takahashi, Kazutoshi; Yamanaka, Shinya

\section{CITATION:}

Okita, Keisuke ... [et al]. Generation of mouse-induced pluripotent stem cells with plasmid vectors.. Nature protocols 2010, 5(3): 418-428

\section{ISSUE DATE:}

2010-02

URL:

http://hdl.handle.net/2433/139480

\section{RIGHT:}

(c) 2010 Nature Publishing Group, a division of Macmillan Publishers

Limited.; This is not the published version. Please cite only the

published version.; この論文は出版社版でありません。引用の際には 出版社版をご確認ご利用ください。 


\section{Generation of Mouse Induced Pluripotent Stem Cells with Plasmid Vectors}

Keisuke Okita ${ }^{1}$, Hyenjong Hong ${ }^{2}$, Kazutoshi Takahashi ${ }^{1}$, and Shinya Yamanaka ${ }^{1 \sim 4}$

${ }^{1}$ Center for iPS Cell Research and Application (CiRA), Institute for Integrated

Cell-Material Sciences, Kyoto University, Kyoto 606-8507, Japan

${ }^{2}$ Department of Stem Cell Biology, Institute for Frontier Medical Sciences, Kyoto

University, Kyoto 606-8507, Japan

${ }^{3}$ CREST and Yamanaka iPS Cell Project, Japan Science and Technology Agency,

Kawaguchi 332-0012, Japan.

${ }^{4}$ Gladstone Institute of Cardiovascular Disease, San Francisco, CA 94158

Keisuke Okita(okita@cira.kyoto-u.ac.jp)

Hyenjong Hong (h-hong@frontier.kyoto-u.ac.jp)

Kazutoshi Takahashi (takahash@cira.kyoto-u.ac.jp)

Shinya Yamanaka (yamanaka@,cira.kyoto-u.ac.jp)

Correspondence should be addressed to K. O. (okita@cira.kyoto-u.ac.jp) 


\section{ABSTRACT}

Reprogramming of somatic cells into pluripotent stem cells has been reported by introducing several transcription factors (Oct3/4, Sox2, c-Myc, and Klf4) in combination. The induced pluripotent stem (iPS) cells from patient's somatic cells would be useful source for drug discovery and cell transplantation therapies. However, most iPS cells were made by virus vectors, such as retrovirus and lentivirus. These vectors integrate host genome and increase the risk of tumor formation. Here we describe the detailed method to generate iPS cells by continual transfection of plasmid vectors from mouse embryonic fibroblasts (MEF). This protocol takes around 2 months from MEF isolation to iPS cell establishment. Still the reprogramming efficiency was low, the established iPS cells were most likely free from plasmid integration. This virus-free technique would advance the safety concern of iPS cell generation and usages, and provide you the cells for the investigation of mechanisms underlying reprogramming and pluripotency. 


\section{INTRODUCTION}

Induced pluripotent stem (iPS) cells are able to be generated from somatic cells by

several combination of transcription factors (Oct3/4, Sox2, Klf4 and c-Myc) and chemical

compounds in mouse and human ${ }^{1,2,3,4}$. They are similar to ES cells in morphology, proliferation

and gene expression profile. Mouse iPS cells can differentiate into all three germ layers and

contributed chimera mice when injected into blastocysts ${ }^{5,6,7}$. Human iPS cells can differentiate

into neuron and cardiomyocyte in vitro ${ }^{3}$. These iPS cells would supply patient-specific

pluripotent stem cells for elucidation of pathogenesis, drug discovery, toxicology study, and cell

transplantation therapy. However, original method of iPS generation used retrovirus vectors,

which integrate the reprogramming factors into host genome. One of the factors, c-Myc, is

known as proto-oncogene, and its reactivation could give rise to transgene deriving-tumor

formation ${ }^{6}$. To overcome the safety concern of iPS generation, several protocols were reported,

such as omission of c-Myc from the reprogramming factors, removal of the integrated factors

after iPS establishment, and transient expression of the factors using adenovirus vectors ${ }^{1,8,9,10}$.

Here we describe the detailed protocol of iPS cell generation by transient expression of the

reprogramming factors using plasmid vectors ${ }^{11}$. We designed two plasmids; one encoding

Oct3/4, Klf4, and Sox2, and the other encoding c-Myc (Fig. 1a). The former 3 transcription

factors are connected with 2A self-cleaving peptide of foot-and-mouth disease virus, which 
enable polycistronic expression of these proteins from one coding region ${ }^{12,13}$. Repeated

transfection of the plasmids can induce pluripotent stem cells from mouse embryonic fibroblasts

(MEF; summarized in Fig. 1b). We provide protocols for MEF isolation, feeder preparation, iPS

induction with the plasmids, and PCR screening to obtain iPS cells without any evidence of

genomic integration. Although we could not rule out the integration of short fragment, at least

they don't have functional transgene. The plasmid-iPS cells can develop teratomas when

subcutaneously injected into nude mice and contribute to adult chimeras. With this

protocol, you do not need infectious viral vectors to generate iPS cells. Since the estimated

established rate of plasmid-iPS is much lower than that of viral induction, this method would be

an important step to improve the safety concern of iPS cells for future medical application.

\section{MATERIALS}

\section{REAGENTS}

- pCX expression vectors $^{14}$ (see REAGENT SETUP)

- $\quad$ Nanog $^{\text {GFP-IRES-Puro }}$ mice $^{6}$ (see REAGENT SETUP)

CAUTION Experiments involving live rodents must conform to International and

Institutional regulations.

- $\quad$ SNL feeder cells ${ }^{15}$ (see REAGENT SETUP) 
- DMEM containing $4.5 \mathrm{~g} \mathrm{l}^{-1}$ glucose (Nacalai tesque, cat. No. 14247-15)

- PBS without calcium and magnesium (Nacalai tesque, cat. no. 14249-95)

- $\quad$ L-Gln (Invitrogen, cat. no. 25030-081)

- Nonessential amino acid solution (Invitrogen, cat. no. 11140-050)

- 2-Mercaptoethanol (Invitrogen, cat. no. 21985-023)

- Penicillin/streptomycin (Invitrogen, cat. no. 15140-122)

- $0.25 \%(\mathrm{wt} / \mathrm{vol}$ ) Trypsin/1 mM EDTA solution (Invitrogen, cat. no. 25200-056)

- $0.5 \%$ (wt/vol) Trypsin/5.3 mM EDTA solution (Invitrogen, cat. no. 25300-054) (see REAGENT SETUP)

- Gelatin (Sigma, cat. no. G1890) (see REAGENT SETUP)

- Puromycin (Sigma, cat. no. P7255) (see REAGENT SETUP)

- Opti-MEM I Reduced-Serum Medium (Invitrogen, cat. no. 31985-062)

- FuGENE 6 transfection reagent (Roche, cat. no. 11814443 001)

- Methanol (Nacalai tesque, cat. no. 12915-93)

- Crystal violet (Nacalai tesque, cat. no. 09804-52) (see REAGENT SETUP)

- ES medium (see REAGENT SETUP)

- SNL medium (see REAGENT SETUP)

- FP medium (see REAGENT SETUP) 
- Proteinase K (Nacalai tesque, cat. no. 29442-14) (see REAGENT SETUP)

- TaKaRa Ex Taq (Takara bio, cat. no. RR001A)

- Cell lysis buffer (see REAGENT SETUP)

\section{EQUIPMENT}

- 100-mm tissue culture dish (Falcon, cat. no. 353003)

- 6-well tissue culture plate (Falcon, cat. no. 353046)

- 24-well tissue culture plate (Falcon, cat. no. 353047)

- 96-well tissue culture plate (Falcon, cat. no. 351172)

- 15-ml conical tube (Falcon, cat. no. 352196)

- 50-ml conical tube (Falcon, cat. no. 352070)

- 1-ml plastic disposable pipette (Falcon, cat. no. 357520)

- 5-ml plastic disposable pipette (Falcon, cat. no. 357543)

- 10-ml plastic disposable pipette (Falcon, cat. no. 357551)

- 25-ml plastic disposable pipette (Falcon, cat. no. 357525)

- Bottle-top filter (Techno Plastic Products, cat. no. 99500)

- $\quad 0.22-\mu \mathrm{m}$ pore size filter (Millex GP; Millipore, cat. no. SLGP033RS)

- 10-ml disposable syringe (Terumo, cat. no. SS-10ESZ) 
- Dissecting forceps CAUTION Sterilize by autoclave

- Dissecting scissors CAUTION Sterilize by autoclave

- Coulter counter (Z2; Beckman Coulter)

- $\mathrm{CO}_{2}$ incubator

- Thermal cycler

- $\quad$ 0.2-ml PCR tube (Greiner bio-one, cat. no. 301301)

- Freezing container (Nalgene, cat. no. 5100-0001)

\section{REAGENT SETUP}

\section{pCX expression vector containing cDNAs of Oct3/4, Sox2, Klf4, or c-Myc}

Available from addgene (http://www.addgene.org/Shinya Yamanaka). We use a pCX expression vector encoding the red fluorescence protein (DsRedExpress) to monitor transfection efficiency.

It also serves as a negative control for iPS cell induction.

\section{Nanog $^{\text {GFP-IRES-Puro }}$ mice}

Available from Riken Bioresource Center (http://www.brc.riken.jp/inf/en/index.shtml, BRC

no. RBRC02290). The reporter cassette GFP-IRES-Puro ${ }^{\mathrm{R}}$ was introduced into 5' untranslated region of the Nanog gene in a bacterial artificial chromosome (BAC). The modified BAC was 
linearized and introduced into RF8 ES cells by electroporation. ES cells containing the modified

BAC were injected into blastocysts to generate Nanog-GFP reporter mice.

\section{SNL feeder cells}

Available from Dr. Allan Bradley of the Sanger Institute (http://www.sanger.ac.uk/) or Health

Protection Agency Culture Collections (http://www.hpacultures.org.uk/). SNL cells were

clonally derived from a STO cell line and stably express a neomycin resistance cassette and a

leukaemia inhibitory factor expression construct. SNLP 76/7-4 feeder cell line, which is

puromycin-resistant derivative of SNL, is also available from Dr. Allan Bradley.

\section{Gelatin-coated culture dishes}

Prepare gelatin stock at $10 \times$ concentration $(1 \% \mathrm{wt} / \mathrm{vol})$. Dissolve $1 \mathrm{~g}$ of gelatin powder in 100

$\mathrm{ml}$ of distilled water, autoclave and store at $4{ }^{\circ} \mathrm{C}$. To prepare $0.1 \%(1 \times)$ gelatin solution, warm

the $10 \times$ gelatin stock in a water bath at $37^{\circ} \mathrm{C}$, add $50 \mathrm{ml}$ of the stock into $450 \mathrm{ml}$ of distilled

water. Filter the solution with a bottle-top filter $(0.22-\mu \mathrm{m})$ and store at $4{ }^{\circ} \mathrm{C}$. To coat a culture

dish, add enough volume of $0.1 \%$ gelatin solution to cover the entire area of the dish bottom.

For example, 1, 3 or $5 \mathrm{ml}$ of gelatin solution is used for a 35-, 60- or 100-mm dish, respectively.

Incubate the dish for at least half an hour at $37^{\circ} \mathrm{C}$. Before using, aspirate excess gelatin solution. 


\section{5\% Trypsin/5.3 mM EDTA solution}

To prepare $0.05 \%$ trypsin/ $/ 0.53 \mathrm{mM}$ EDTA, mix $10 \mathrm{ml}$ of $0.5 \%$ trypsin $/ 5.3 \mathrm{mM}$ EDTA solution with $90 \mathrm{ml}$ of PBS. To prepare $0.1 \%$ trypsin/ $1 \mathrm{mM}$ EDTA, add $20 \mathrm{ml}$ of $0.5 \%$ trypsin $/ 5.3 \mathrm{mM}$ EDTA to $80 \mathrm{ml}$ of PBS. Aliquot and store at $-20^{\circ} \mathrm{C}$.

\section{Puromycin}

Dissolve in distilled water at $10 \mathrm{mg} \mathrm{ml}^{-1}$ and sterilize through a $0.22-\mu \mathrm{m}$ filter. Aliquot and store at $-20{ }^{\circ} \mathrm{C}$.

\section{Crystal violet}

Working solution is $0.1 \%$ (wt/vol). Dissolve $0.1 \mathrm{~g}$ of crystal violet in $100 \mathrm{ml}$ of methanol.

\section{ES medium}

DMEM containing $15 \% \mathrm{FBS}(\mathrm{vol} / \mathrm{vol}), 2 \mathrm{mM}_{\mathrm{L}}-\mathrm{Gln}, 1 \times 10^{-4} \mathrm{M}$ non-essential amino acids, $1 \times$ $10^{-4} \mathrm{M}$ 2-mercaptoethanol, and $50 \mathrm{U}$ and $50 \mathrm{mg} \mathrm{ml}^{-1}$ penicillin and streptomycin. To prepare 500 $\mathrm{ml}$ of the medium, mix $75 \mathrm{ml}$ of FBS, $5 \mathrm{ml}$ of ${ }_{\mathrm{L}}$-Gln, $5 \mathrm{ml}$ of nonessential amino acids, $1 \mathrm{ml}$ of 2-mercaptoethanol and $2.5 \mathrm{ml}$ of penicillin/streptomycin, and then fill to $500 \mathrm{ml}$ with DMEM. 
Store at $4{ }^{\circ} \mathrm{C}$ for a week.

\section{SNL medium}

DMEM containing 7\% FBS, $2 \mathrm{mM}_{\mathrm{L}^{-}} \mathrm{Gln}$, and $50 \mathrm{U}$ and $50 \mathrm{mg} \mathrm{ml}^{-1}$ penicillin and streptomycin.

To prepare $500 \mathrm{ml}$ of the medium, mix $35 \mathrm{ml}$ of FBS, $5 \mathrm{ml}$ of ${ }_{\mathrm{L}}$-Gln and $2.5 \mathrm{ml}$ of

penicillin/streptomycin, and then fill to $500 \mathrm{ml}$ with DMEM. Store at $4{ }^{\circ} \mathrm{C}$ for a week.

\section{FP medium}

DMEM containing $10 \% \mathrm{FBS}$, and $50 \mathrm{U}$ and $50 \mathrm{mg} \mathrm{ml}^{-1}$ penicillin and streptomycin. To prepare

$500 \mathrm{ml}$ of FP medium, mix $50 \mathrm{ml}$ of FBS and $2.5 \mathrm{ml}$ of penicillin/streptomycin, and then fill to

$500 \mathrm{ml}$ with DMEM. Store at $4{ }^{\circ} \mathrm{C}$ for a week.

\section{$2 \times$ Freezing medium}

To make $10 \mathrm{ml}$ of $2 \times$ freezing medium, mix $2 \mathrm{ml}$ of DMSO, $2 \mathrm{ml}$ of FBS and $6 \mathrm{ml}$ of DMEM, and sterilize through a $0.22 \mu \mathrm{m}$ filter.

\section{Proteinase $\mathrm{K}$}

Dissolve in distilled water at $10 \mathrm{mg} \mathrm{ml}^{-1}$. Aliquot and store at $-20{ }^{\circ} \mathrm{C}$. 


\section{Cell lysis buffer}

PCR buffer containing $150 \mu \mathrm{g} \mathrm{ml}^{-1}$ of Proteinase $\mathrm{K}$. To prepare $100 \mu \mathrm{l}$ of cell lysis buffer, mix $10 \mu \mathrm{l}$ of $10 \times$ Ex Taq buffer containing magnesium, $1.5 \mu \mathrm{lof} 10 \mathrm{mg} \mathrm{ml}^{-1}$ Proteinase $\mathrm{K}$ and 88.5 $\mu l$ of distilled water.

\section{PROCEDURE}

Preparation of fibroblasts from mouse embryos; TIMING $15 \mathrm{~d}$

1. Euthanize 13.5-day pregnant female mice by cervical dislocation. Isolate uteri and wash with PBS briefly.

2. Separate embryos from their placenta and surrounding membranes with forceps. Remove the head, visceral tissues, and gonads from isolated embryos.

3. Wash embryos by transferring it to a $100-\mathrm{mm}$ dish containing fresh PBS. Mince the bodies by using a pair of scissors, transfer into a $50-\mathrm{ml}$ conical tube containing $0.1 \%$ trypsin/0.1 mM EDTA solution ( $3 \mathrm{ml}$ per embryo), and incubate at $37^{\circ} \mathrm{C}$ for $20 \mathrm{~min}$.

4. Add additional $0.1 \%$ trypsin/ $/ 0.1 \mathrm{mM}$ EDTA solution ( $3 \mathrm{ml}$ per embryo), and incubate the mixture at $37{ }^{\circ} \mathrm{C}$ for $20 \mathrm{~min}$.

5. Add an equal amount of FP medium ( $6 \mathrm{ml}$ per embryo), and pipette up and down a few 
times to help with tissue dissociation.

6. Keep the tissue/medium mixture still for $5 \mathrm{~min}$ at room temperature $\left(20 \sim 25^{\circ} \mathrm{C}\right)$ to remove debris, and transfer the supernatant into a new 50-ml conical tube. Centrifuge at $200 \mathrm{~g}$ for 5 min, discard the supernatant, and resuspend the pellet in fresh medium.

7. Count the cell number and adjust the concentration to $1 \times 10^{6}$ cells $\mathrm{ml}^{-1}$ with FP medium.

Generally, approximately $1 \times 10^{7}$ cells can be obtained from a single embryo. Transfer the cell suspension to 100 -mm tissue culture dishes $\left(1 \times 10^{7}\right.$ cells per dish $)$ and incubate at 37 ${ }^{\circ} \mathrm{C}$ with $5 \% \mathrm{CO}_{2}$ for $24 \mathrm{~h}$ (passage 1).

8. The next day, remove floating cells by washing with PBS, and add new FP medium..

9. When the cells become confluent (generally 2 or $3 \mathrm{~d}$ after the isolation), you can pass or store the cells. For passage, remove FP medium, wash once with PBS, and trypsinize with $1 \mathrm{ml}$ of $0.05 \%$ trypsin/ $0.53 \mathrm{mM}$ EDTA for a $5 \mathrm{~min}$. After detaching, add $9 \mathrm{ml}$ of FP medium and suspend by pipetting. Passage to new 100-mm dishes at 1:4 dilution (passage 2). For the generation of iPS cells, we used MEFs within three passages to avoid replicative senescence.

Preparation of freeze stock of MEF; TIMING $1 \mathrm{~h}$

10. Aspirate the medium, and wash the cells with $5 \mathrm{ml}$ of PBS. 
11. Remove PBS completely, add $1 \mathrm{ml}$ of $0.05 \%$ trypsin/ $0.53 \mathrm{mM}$ EDTA and incubate at $37{ }^{\circ} \mathrm{C}$ for $5 \mathrm{~min}$.

12. Add $9 \mathrm{ml}$ of the FP medium and suspend the cells by pipetting up and down to single cell suspension.

13. Transfer the cell suspension to a $15-\mathrm{ml}$ tube, count the cell number and spin the cells at 160 $g$ for $5 \mathrm{~min}$.

14. Discard the supernatant, and resuspend the cells with FP medium to the concentration at 1 $\times 10^{7}$ cells per milliliter.

15. Prepare $2 \times$ freezing medium and aliquot it at $0.5 \mathrm{ml}$ per vial.

16. Transfer $0.5 \mathrm{ml}$ of the cell suspension to freeze vials and mix gently.

17. Put the vials in a cell-freezing container and keep it at $-80{ }^{\circ} \mathrm{C}$ overnight.

PAUSE POINT For long-term storage, keep frozen cells in the gas phase of a liquid nitrogen tank.

Thawing SNL cells; TIMING $0.5 \mathrm{~h}$

18. Prepare $9 \mathrm{ml}$ of SNL medium in a $15-\mathrm{ml}$ tube.

19. Remove a vial of frozen SNL cells from the liquid nitrogen tank and put the vial into $37{ }^{\circ} \mathrm{C}$ water bath until most (but not all) cells are thawed. 
20. Wipe the vial with ethanol, open the cap, and transfer the cell suspension to the tube prepared in step 18 .

21. Centrifuge at $160 \mathrm{~g}$ for $5 \mathrm{~min}$, and then discard the supernatant.

22. Resuspend the cells with $10 \mathrm{ml}$ of SNL medium, and transfer to a gelatin-coated 100-mm dish. Incubate the cells in a $37{ }^{\circ} \mathrm{C}, 5 \% \mathrm{CO}_{2}$ incubator, until the cells become $80 \sim 90 \%$ confluent.

CRITICAL STEP Do not let the cells get over-confluent, or their ability as feeder cells may decrease.

Passage of SNL cells; TIMING $0.5 \mathrm{~h}$

23. Discard the medium and wash the cells once with PBS.

24. Aspirate PBS, and add $0.5 \mathrm{ml}$ per dish of $0.25 \%$ trypsin $/ 1 \mathrm{mM}$ EDTA, and incubate for 1 min at room temperature.

25. Add $4.5 \mathrm{ml}$ of SNL medium, and break up the cells into a single cell suspension by pipetting up and down several times.

26. Adjust the cell suspension to $160 \mathrm{ml}$ by addition of SNL medium, and transfer to gelatin-coated dishes (10 ml per 100-mm dish). This splits the cells 1:16. Incubate the cells at $37{ }^{\circ} \mathrm{C}, 5 \% \mathrm{CO}_{2}$ until the cells become $80-90 \%$ confluent. This should be happen $3-4 \mathrm{~d}$ 
after passage.

\section{Mitomycin C-inactivation of SNL cells; TIMING $3 \mathrm{~h}$}

27. Add $0.3 \mathrm{ml}$ of $0.4 \mathrm{mg} \mathrm{ml}^{-1}$ mitomycin C solution directly to the culture medium of SNL

dish, swirl it briefly, and incubate $2.25 \mathrm{~h}$ at $37{ }^{\circ} \mathrm{C}, 5 \% \mathrm{CO}_{2}$. The final concentration of mitomycin C will be $12 \mu \mathrm{g} \mathrm{ml}^{-1}$.

28. After incubation, aspirate the mitomycin C-containing medium off the cells, and wash the cells twice with $10 \mathrm{ml}$ of PBS.

29. Aspirate off PBS, add $0.5 \mathrm{ml}$ of $0.25 \%$ trypsin/ $1 \mathrm{mM}$ EDTA, swirl to cover the entire surface, and let sit for $1 \mathrm{~min}$ at room temperature.

30. Neutralize the trypsin by adding $5 \mathrm{ml}$ of SNL medium, and break up the cells to a single cell suspension by pipetting up and down. Pour the cell suspension into a 50-ml tube and count the cell number. Seed the cells on gelatin-coated dishes $\left(1 \times 10^{6}\right.$ cells per $100-\mathrm{mm}$ tissue culture dish, or $1.5 \times 10^{5}$ cells per well of 6-well plate).

31. Cells should be nicely spread with little gaps in between. They should become ready for usage by the next day.

PAUSE POINT The mitomycin C-treated SNL dishes can be left for up to a week before use.

Note: Mitomycin C-treated MEF could be used as feeders, but SNL seems to work slightly 
better.

\section{iPS induction with plasmid vector.}

To use frozen stock of MEF, thaw the cells same as the protocols of thawing SNL cells (steps

18-22), except using FP medium instead of SNL medium.

\section{Day 1: Preparation of fibroblasts; TIMING $1 \mathrm{~h}$}

32. Culture MEF (passage $<3$ ) to $\sim 90 \%$ confluency in 100 -mm dishes $\left(\sim 2 \times 10^{6}\right.$ cells per dish).

33. Aspirate the culture medium and wash with $10 \mathrm{ml}$ of PBS.

34. Discard PBS, add $1 \mathrm{ml}$ per dish of $0.05 \%$ trypsin $/ 0.53 \mathrm{mM}$ EDTA, and incubate at $37^{\circ} \mathrm{C}$ for $5 \mathrm{~min}$

35. Add $9 \mathrm{ml}$ of FP medium, suspend the cells to a single cell, and transfer to a 50-ml tube.

36. Count cell numbers, and adjust the concentration to $6.5 \times 10^{4}$ cells ml ${ }^{-1}$. Transfer $2 \mathrm{ml}$ of cell suspension $\left(1.3 \times 10^{5}\right.$ cells $)$ to each well of 6 -well plate. Incubate the dish overnight at $37{ }^{\circ} \mathrm{C}, 5 \% \mathrm{CO}_{2}$.

\section{Day 2: Plasmid transfection; TIMING $1 \mathrm{~h}$}

37. Aspirate the medium from a fibroblast dish, and add $2 \mathrm{ml}$ of fresh FP medium. 
38. Transfer $0.1 \mathrm{ml}$ of Opti-MEM into a 1.5-ml tube.

39. Transfer $4.5 \mu$ of FuGENE 6 transfection reagent directly into Opti-MEM prepared in step

38 , mix gently by finger tapping, and incubate for $5 \mathrm{~min}$ at room temperature.

40. Mix $1.0 \mu \mathrm{g}$ of $\mathrm{pCX}-\mathrm{OKS}-2 \mathrm{~A}$ and $0.5 \mu \mathrm{g}$ of $\mathrm{pCX}-\mathrm{cMyc}$, add them into the FuGENE

6/Opti-MEM containing tube, mix gently by finger tapping, and incubate for $15 \mathrm{~min}$.

41. Add the DNA/FuGENE 6 complex dropwise into the fibroblast dish, and incubate overnight at $37^{\circ} \mathrm{C}, 5 \% \mathrm{CO}_{2}$.

CRITICAL STEP Also transfect with a suitable control; we use pCX vector encoding

DsRedExpress to monitor transfection efficiency. We routinely obtain efficiency of more than

$40 \%$ examined on day 10 (Fig. 2). High efficiency of transfection is crucial for iPS cell

induction.

Day 3: Medium change; TIMING 5 min

42. Aspirate the medium from a fibroblast dish, and add $2 \mathrm{ml}$ of fresh FP medium.

Day 4: Plasmid transfection; TIMING $1 \mathrm{~h}$

43. Same as steps $37-41$. 
Day 5: Medium change; TIMING 5 min

44. Aspirate the medium from a fibroblast dish, and add $2 \mathrm{ml}$ of fresh ES medium.

Day 6: Plasmid transfection; TIMING $1 \mathrm{~h}$

45. Carry out same as steps 37-41 except that ES medium is used instead of FP medium.

Day 7: Medium change; TIMING 5 min

46. Aspirate the medium from a fibroblast dish, and add $2 \mathrm{ml}$ of fresh ES medium.

Day 8: Plasmid transfection; TIMING $1 \mathrm{~h}$

47. Carry out same as steps 37-41 except that ES medium is used instead of FP medium.

Day 9: Medium change; TIMING 5 min

48. Aspirate the medium from a fibroblast dish, and add $2 \mathrm{ml}$ of fresh ES medium.

Day 10: Passage of fibroblast; TIMING $1 \mathrm{~h}$

49. Discard the medium and wash the cells once with PBS.

50. Aspirate PBS, and add $0.5 \mathrm{ml}$ per dish of $0.25 \%$ trypsin $/ 1 \mathrm{mM}$ EDTA, and incubate for 5 
$\mathrm{min}$ at room temperature.

51. Add $4.5 \mathrm{ml}$ of ES medium, and break up the cells into a single cell suspension by pipetting up and down several times.

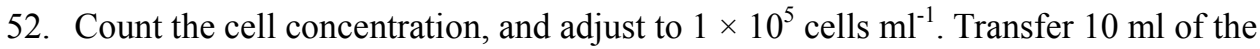
suspension $\left(1 \times 10^{6}\right.$ cells $)$ to $100-\mathrm{mm}$ dish covered with mitomycin C-inactivated SNL cells.

Gelatin-coated dishes are also available, but they would reduce induction efficiency. Incubate the cells at $37^{\circ} \mathrm{C}, 5 \% \mathrm{CO}_{2}$.

Day 11 : Medium change; TIMING 5 min. each day

53. Change the medium every other day until the colonies become big enough to be picked up

(Fig. 3). Colonies should first become visible approximately on day 20. They should

become large enough to be picked up around day 30. If you use fibroblasts from

Nanog ${ }^{\text {GFP-IRES-Puro }}$ mice, the fluorescence will help you to choose colonies. We found that some GFP-negative or weak colonies become GFP-positive after picking up.

TROUBLESHOOTING

Picking up the iPS colonies; TIMING $1 \mathrm{~h}$

54. Aliquot $20 \mu 1$ of $0.25 \%$ trypsin/ $1 \mathrm{mM}$ EDTA per well of $96-$ well plate. 
55. Remove the medium from the dish, and add $10 \mathrm{ml}$ of PBS.

56. Aspirate PBS, and add $5 \mathrm{ml}$ of PBS.

57. Pick colonies from the dish using a Pipetman set at $2 \mu 1$, and transfer it into the 96 -well trypsin plate. Pick up as many colonies as you can within $15 \mathrm{~min}$. Incubate another $15 \mathrm{~min}$ in trypsin at $37^{\circ} \mathrm{C}$ to dissociate cells in the colonies.

58. Add $180 \mu \mathrm{l}$ of ES medium to each well, and pipette up and down to break up the colony to single cells.

59. Transfer cell suspension into the wells of 24-well plates with SNL feeder cells (use puromycin-resistant feeder cells for Nanog ${ }^{\text {GFP-IRES-Puro }}$ ), add $300 \mu \mathrm{l}$ ES medium, and incubate in $37^{\circ} \mathrm{C}, 5 \% \mathrm{CO}_{2}$ incubator until the cells reach 50 60\% confluency. Treatment of puromycin $\left(1.5 \mu \mathrm{g} \mathrm{ml}^{-1}\right)$ support to select highly reprogrammed cells. At this point they could be screened by genomic PCR to exclude clones with apparent integrations (see steps $65 \sim 72)$.

Counting the colonies: $\quad$ staining with crystal violet; TIMING $1 \mathrm{~d}$

60. After picking the colonies, aspirate PBS completely from the $100-\mathrm{mm}$ dish and then add 5 $\mathrm{ml}$ of methanol to fix the remaining cells. Incubate for $1 \mathrm{~min}$ at room temperature.

61. Wash the dishes twice with water. 
62. Add $5 \mathrm{ml}$ of $0.1 \%$ crystal violet solution into the dish and incubate for $5 \mathrm{~min}$ at room temperature.

63. Wash the dishes with water.

64. Photograph the dishes and count the number of colonies.

\section{Examination of genomic integration; TIMING $1 \mathrm{~d}$}

65. Aliquot $5 \mu \mathrm{l}$ of cell lysis buffer per tube of $0.2-\mathrm{ml}$ PCR tube.

66. Aspirate the medium, and wash the cells with $0.5 \mathrm{ml}$ of PBS.

67. Remove PBS, and add $0.5 \mathrm{ml}$ of PBS.

68. Pick a part of colonies (approximately $0.5 \mu 1$ of volume) from the dish using a Pipetman set at $2 \mu \mathrm{l}$, and transfer it into the cell lysis buffer.

69. After picking the colonies, aspirate PBS completely from culture dishes and then add 0.5 $\mathrm{ml}$ of ES medium, and return them in $37{ }^{\circ} \mathrm{C}, 5 \% \mathrm{CO}_{2}$ incubator until the cells reach $80 \sim 90 \%$ confluency.

70. Incubate cell lysis buffer at $55^{\circ} \mathrm{C}$ for $4-12 \mathrm{~h}$ in humidified chamber.

71. Add $10 \mu \mathrm{l}$ of distilled water, and incubate at $95^{\circ} \mathrm{C}$ for $3 \mathrm{~min}$ to inactivate proteinase.

72. Use $1 \mu \mathrm{l}$ of the solution for PCR to detect genomic integration. Primer sequences and PCR conditions are listed in table 1 . Select clones which do not show obvious integration for 
further cultivation (Fig. 4).

TROUBLESHOOTING

\section{Expansion of iPS cells; TIMING $1 \mathrm{~h}$}

73. Aspirate the medium, and wash the cells with $1 \mathrm{ml}$ of PBS.

74. Remove PBS completely, add $0.1 \mathrm{ml}$ of $0.25 \%$ trypsin $/ 1 \mathrm{mM}$ EDTA and incubate at $37{ }^{\circ} \mathrm{C}$ for $10 \mathrm{~min}$.

75. Add $0.4 \mathrm{ml}$ of the ES medium and suspend the cells by pipetting up and down to single cell suspension.

76. Transfer the cell suspension to a well of 6-well plate with SNL feeder cells (use puromycin-resistant feeder cells for Nanog ${ }^{\text {GFP-IRES-Puro }}$ ), add $1.5 \mathrm{ml}$ ES cell medium, and incubate in $37^{\circ} \mathrm{C}, 5 \% \mathrm{CO}_{2}$ incubator. Addition of puromycin $\left(1.5 \mu \mathrm{g} \mathrm{m}{ }^{-1}\right)$ support to select highly reprogrammed cells. When the cells reach $80 \sim 90 \%$ confluency, prepare frozen stock of the cells, as follows.

TROUBLESHOOTING

Preparation of freeze stock; TIMING $1 \mathrm{~h}$

77. Aspirate the medium, and wash the cells with $2 \mathrm{ml}$ of PBS. 
78. Remove PBS completely, add $0.3 \mathrm{ml}$ of $0.25 \%$ trypsin $/ 1 \mathrm{mM}$ EDTA and incubate at $37{ }^{\circ} \mathrm{C}$ for $10 \mathrm{~min}$.

79. Add $2 \mathrm{ml}$ of the ES medium and suspend the cells by pipetting up and down to single cell suspension.

80. Transfer the cell suspension to a $15-\mathrm{ml}$ tube, count the cell number and spin the cells at 160 $g$ for $5 \mathrm{~min}$.

81. Discard the supernatant, and resuspend the cells with ES medium to the concentration at 2 $\times 10^{6}$ cells per milliliter.

82. Prepare $2 \times$ freezing medium and aliquot it at $0.5 \mathrm{ml}$ per vial.

83. Transfer $0.5 \mathrm{ml}$ of the cell suspension to freeze vials and mix gently.

84. Put the vials in a cell-freezing container and keep it at $-80{ }^{\circ} \mathrm{C}$ overnight.

PAUSE POINT For long-term storage, keep frozen cells in the gas phase of a liquid nitrogen tank.

TROUBLESHOOTING

\section{Troubleshooting}

\section{PROBLEM}

No colonies appear after induction of the four factors. 


\section{SOLUTION}

The efficiency of colony formation is low with the plasmid-based method. Approximately $10 \%$

of experiments can not obtain any colony (including non-ES like colony). Try another

experiment. The transfection efficiency of plasmid is important, therefore use high quality of

plasmid for the induction, and avoid repetitive freeze-and-thaw cycle to prevent DNA nicking

and degradation. We use anion-exchange based column (QIAGEN plasmid kit; QIAGEN) to

purify the plasmids, aliquot the plasmids, and store at $-20{ }^{\circ} \mathrm{C}$. Age of fibroblast (passage

number) is also critical for iPS generation. We recommend using MEFs within passage 3 for iPS

production. Also make sure that your ES medium can maintain mouse ES or iPS cells.

\section{PROBLEM}

Too many non-ES-like colonies appear after the induction.

\section{SOLUTION}

In some experiments (approximately 10\%) more than 500 colonies appeared. It may because

transfected plasmid(s) were integrated into fibroblast's genome and transformed them to

non-ES-like cells in the early period of the induction. After several rounds of proliferation, they

would spread out the 100 -mm dish by the passage on day 10 . In these cases, we could not obtain

iPS clones without apparent integration. Try another experiment. 


\section{PROBLEM}

Isolated clone is not pluripotent.

SOLUTION

Choose the superior clones by morphologies and marker gene expression. As iPS clones having

genomic integration tend to become transformed, select the clones without apparent integration.

\section{PROBLEM}

The characters and potentials of iPS cell change during culture.

\section{SOLUTION}

iPS cells are less stable than ES cells. Make large amount of freeze stocks of iPS clones at early passages. These stocks should be stored in the vapor phase of liquid nitrogen. The recovery of iPS cells after freezing is approximately $50 \%$. Continuous selection with antibiotics facilitates stability of iPS cells. In some cases, granulated (not ES-like) cells emerge in iPS cell cultures.

The loosely attached GFP-negative cells can easily be washed out with PBS or can be removed by antibiotic selection.

\section{ANTICIPATED RESULTS}


During the series of plasmid transfection, some floating cells appear because of the cytotoxicity of repeated transfection. However, other cells grow robustly and become confluent around day 10.The transfection efficiency could be more than $40 \%$ if the procedure went well. The transfection efficiency can be evaluated by analyzing DsRedExpress-transfected cells with a flow cytometer (Fig. 2). The efficiency and mean expression level are lower than that of retroviral transduction.

We obtained iPS colonies without evidence of integration from 6 out of 10 experiments, but not from 4 experiments including 1 experiment showing no iPS colony formation. The number of colonies in a 100-mm dish is generally small (below 100). The estimated established rate of plasmid-iPS cells without evidence of integration is $<0.0002 \%$, which is at least 1000 -fold lower than that of viral induction ${ }^{11}$. Although iPS colonies with genomic integration were frequently observed, genomic PCR screening (steps 65 72, Fig. 4) can distinguish them easily. We found that almost one-third of ES-like colonies did not show transgene-derived band in this screening. By using Nanog ${ }^{\text {GFP-IRES-Puro }}$ MEF, GFP-positive cells became first apparent around day 19 after the induction (Fig. 3). Some clones did not show fluorescence at the time of colony picking up. However, they became GFP-positive during the culture in 24-well plate.

After picking up and PCR selection, most clones show ES-like proliferation and 
morphology, including a round shape, large nucleoli, and scant cytoplasm, in ES cell culture

condition. However, some clones show non-ES-like morphology or fail to proliferate. Most

clones express ES cell marker gene, such as Nanog, ERas, Zfp42, and Utf1 ${ }^{16}$. Teratoma

developed by subcutaneous injection into nude mice can be used to demonstrate pluripotency of these cells (Fig. 5a-d). Most clones contribute to adult chimeric mice (Fig. 5e) and some of them transmitted through germline.

\section{ACKNOWLEDGEMENT}

We are grateful to Drs. Masato Nakagawa, Kojiro Yae, Michiyo Koyanagi and Koji Tanabe for scientific discussion, and Kanon Takeda and Tetsuya Ishii for critical reading of this manuscript. We also thank Tomoko Ichisaka, Kanako Okuda, Megumi Narita, Aki Okada, Nanako Takizawa, Rie Kato, Ryoko Iyama, Eri Nishikawa, Yurie Shimazu and Noriyo Maruhashi for technical and administrative supports. We also thank Jun-ichi Miyazaki for the CAG promoter. 


\section{Figure legends}

Figure 1 Schematic diagram of iPS cell generation with plasmid vectors.

a. Expression vectors for iPS cell generation. pCX-OKS-2A (left) encodes three transcription factors (Oct3/4, Sox2, and Klf4) connected with 2A self-cleaving peptide (2A). The locations of CAG promoter (CAG), polyadenylation signal $(\mathrm{pA})$, and ampicillin resistant gene $\left(\mathrm{Amp}^{\mathrm{r}}\right)$ are also indicated. The c-Myc expression vector ( $\mathrm{pCX}-\mathrm{cMyc})$ is on the right. b. Approximate time table of the iPS cell generation.

Figure 2 Transfection efficiency of repeated lipofection.

Expression plasmid encoding DsRedExpress was transfected 4 times with FuGENE6 reagent.

Their fluorescence were photographed on day 10 of the iPS induction and examined by flow cytometory. MEF were also infected with pMXs-based retrovirus encoding DsRedExpress on day 2 , and were analyzed. Bar indicates $500 \mu \mathrm{m}$.

Figure 3 Morphology of iPS colonies just before picking up.

Lower panels showed GFP fluorescence from Nanog ${ }^{\text {GFP-IRES-Puro }}$ locus. Although the right colony barely showed the fluorescence, it became GFP positive after picking up. Bar indicates $500 \mu \mathrm{m}$. 


\section{Figure 4 PCR screening of genomic integration.}

a. Schematic diagram of PCR primers. Open boxes indicate exons of Klf4 (left) and c-Myc

(right), and arrows indicate primer sites. The primers of Klf4 are located on 2 exons flanking

intron. Therefore they amplify $831 \mathrm{bp}$ from endogenous locus, and $186 \mathrm{bp}$ from transgene. The

primers for c-Myc amplify $541 \mathrm{bp}$ from endogenous locus and $237 \mathrm{bp}$ from transgene. $\mathrm{b}$.

Detection of genomic integration by PCR. Open and black arrowheads indicate bands from

endogenous alleles and transgenes, respectively. Retrovirus induced iPS cells (retro-iPS) were

used as control. Some clones ( $\# 2,3$, and 8$)$ do not seem to have integration.

\section{Figure 5 Pluripotency of plasmid-iPS cells.}

Plasmid-iPS cells developed teratoma when subcutaneously transplanted into nude mice (a-d).

Shown are hematoxylin \& eosin staining sections of neural tissue (a), gutlike epithelial tissue

(b), epidermal tissue (c), and striated muscle (d). Bar indicates $50 \mu \mathrm{m}$. e. The iPS cells also

contributed to chimeric mouse. iPS cells gave rise to gray hair. 


\section{REFERENCES}

Takahashi, K. \& Yamanaka, S. Induction of pluripotent stem cells from mouse embryonic and adult fibroblast cultures by defined factors. Cell 126, 663-676 (2006).

3

Takahashi, K. et al. Induction of pluripotent stem cells from adult human fibroblasts by defined factors. Cell 131, 861-872 (2007).

4 Yu, J. et al. Induced pluripotent stem cell lines derived from human somatic cells. Science 318, 1917-1920 (2007).

Stadtfeld, M., Nagaya, M., Utikal, J., Weir, G. \& Hochedlinger, K. Induced pluripotent stem cells generated without viral integration. Science 322, 945-949 (2008).

9

Nakagawa, M. et al. Generation of induced pluripotent stem cells without Myc from mouse and human fibroblasts. Nat Biotechnol 26, 101-106 (2008).

Maherali, N. et al. Directly reprogrammed fibroblasts show global epigenetic remodeling and widespread tissue contribution. Cell Stem Cell 1, 55-70 (2007).

Okita, K., Ichisaka, T. \& Yamanaka, S. Generation of germline-competent induced pluripotent stem cells. Nature 448, 313-317 (2007).

Wernig, M. et al. In vitro reprogramming of fibroblasts into a pluripotent ES-cell-like state.

Nature 448, 318-324 (2007).

Kaji, K. et al. Virus-free induction of pluripotency and subsequent excision of reprogramming 
factors. Nature (2009).

Woltjen, K. et al. piggyBac transposition reprograms fibroblasts to induced pluripotent stem cells. Nature (2009). Okita, K., Nakagawa, M., Hyenjong, H., Ichisaka, T. \& Yamanaka, S. Generation of mouse induced pluripotent stem cells without viral vectors. Science 322, 949-953 (2008).

Donnelly, M. L. et al. The 'cleavage' activities of foot-and-mouth disease virus 2A site-directed mutants and naturally occurring '2A-like' sequences. J Gen Virol 82, 1027-1041 (2001).

Hasegawa, K., Cowan, A. B., Nakatsuji, N. \& Suemori, H. Efficient multicistronic expression of a transgene in human embryonic stem cells. Stem Cells 25, 1707-1712 (2007).

Niwa, H., Yamamura, K. \& Miyazaki, J. Efficient selection for high-expression transfectants with a novel eukaryotic vector. Gene 108, 193-199 (1991). McMahon, A. P. \& Bradley, A. The Wnt-1 (int-1) proto-oncogene is required for development of a large region of the mouse brain. Cell 62, 1073-1085 (1990).

Takahashi, K., Okita, K., Nakagawa, M. \& Yamanaka, S. Induction of pluripotent stem cells from fibroblast cultures. Nat Protoc 2, 3081-3089 (2007). 
Table 1 PCR conditions

\begin{tabular}{|c|c|c|c|c|c|c|}
\hline \multirow{3}{*}{ Gene } & \multirow{3}{*}{ Primer set } & \multicolumn{2}{|l|}{ Initial } & \multirow{3}{*}{ Annealing } & \multirow{3}{*}{ Extension } & \multirow{3}{*}{$\begin{array}{l}\text { Final } \\
\text { Extension }\end{array}$} \\
\hline & & & Denature & & & \\
\hline & & denaturing & & & & \\
\hline \multirow[t]{2}{*}{ Klf4 } & GCG GGA AGG GAG AAG ACA CTG CGT C & $92^{\circ} \mathrm{C}$ & $92^{\circ} \mathrm{C}$ & $64^{\circ} \mathrm{C}$ & $72^{\circ} \mathrm{C}$ & $92^{\circ} \mathrm{C}$ \\
\hline & TAG GAG GGC CGG GTT GTT ACT GCT & $2 \mathrm{~min}$ & $20 \mathrm{sec}$ & $20 \mathrm{sec}$ & $40 \mathrm{sec}$ & $3 \mathrm{~min}$ \\
\hline \multirow[t]{3}{*}{ c-Myc } & ACA CTC CCC CAA CAC CAG GAC GTT T & $92^{\circ} \mathrm{C}$ & $92^{\circ} \mathrm{C}$ & $64^{\circ} \mathrm{C}$ & $72^{\circ} \mathrm{C}$ & $92^{\circ} \mathrm{C}$ \\
\hline & GCT CGC CCA AAT CCT GTA CCT CGT CCG AT & $2 \mathrm{~min}$ & $20 \mathrm{sec}$ & $20 \mathrm{sec}$ & $40 \mathrm{sec}$ & $3 \mathrm{~min}$ \\
\hline & GAG ATG AGC CCG ACT CCG ACC TCT T & & & & & \\
\hline
\end{tabular}


Fig. 1 Okita et al.

a

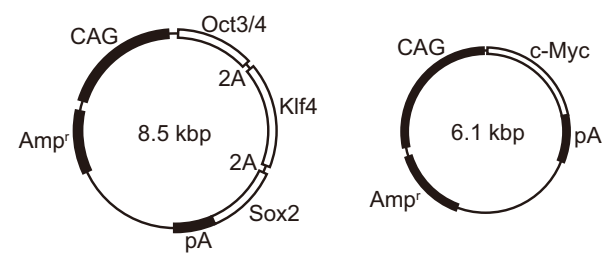

b

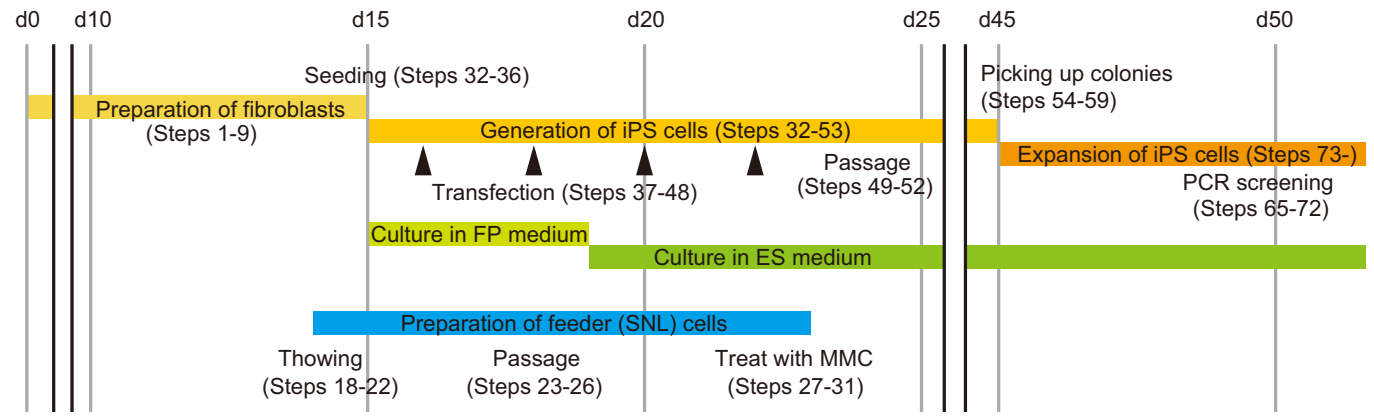

Figure 1 Schematic diagram of iPS cell generation with plasmid vectors.

a. Expression vectors for iPS cell generation. pCX-OKS-2A (left) encodes three transcription factors (Oct3/4, Sox2, and Klf4) connected with 2A self-cleaving peptide (2A). The locations of CAG promoter (CAG), polyadenylation signal $(\mathrm{pA})$, and ampicillin resistant gene (Ampr) are also indicated. The c-Myc expression vector ( $\mathrm{pCX}-\mathrm{cMyc})$ is on the right. $\mathrm{b}$. Approximate time table of the iPS cell generation. 
Fig. 2 Okita et al.

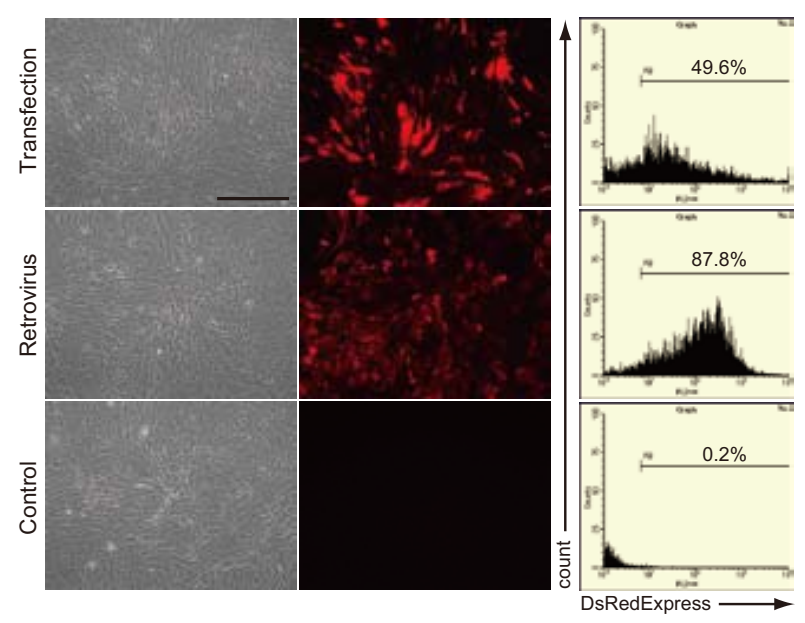

Figure 2 Transfection efficiency of repeated lipofection.

Expression plasmid encoding DsRedExpress was transfected 4 times with FuGENE6 reagent. Their fluorescence were photographed on day 10 of the iPS induction and examined by flow cytometory. MEF were also infected with pMXs-based retrovirus encoding DsRedExpress on day 2, and were analyzed. Bar indicates $500 \mu \mathrm{m}$. 
Fig. 3 Okita et al.

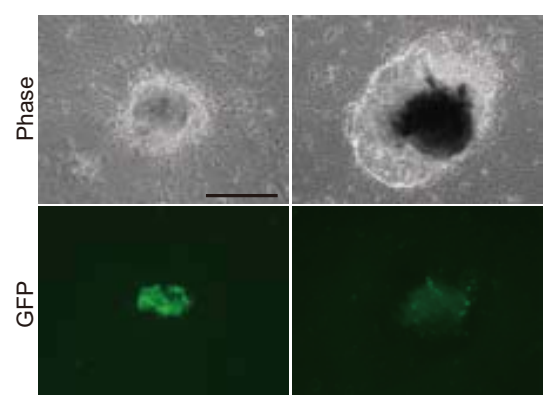

Figure 3 Morphology of iPS colonies just before picking up.

Lower panels showed GFP fluorescence from NanogGFP-IRES-Puro locus. Although the right colony barely showed the fluorescence, it became GFP positive after picking up. Bar indicates $500 \mu \mathrm{m}$. 
Fig. 4 Okita et al.

a

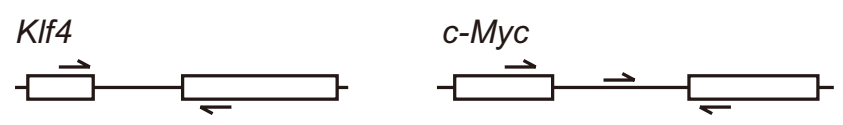

b

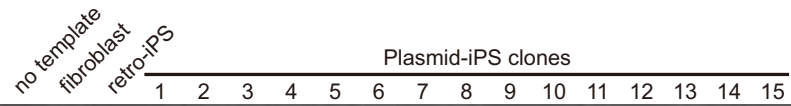

KIf4

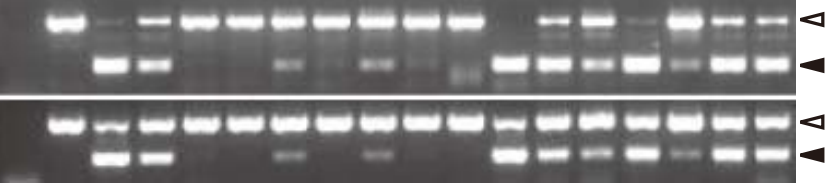

Figure 4 PCR screening of genomic integration.

a. Schematic diagram of PCR primers. Open boxes indicate exons of Klf4 (left) and c-Myc (right), and arrows indicate primer sites. The primers of KIf4 are located on 2 exons flanking intron. Therefore they amplify 831 bp from endogenous locus, and 186 bp from transgene. The primers for c-Myc amplify 541 bp from endogenous locus and $237 \mathrm{bp}$ from transgene. b. Detection of genomic integration by PCR. Open and black arrowheads indicate bands from endogenous alleles and transgenes, respectively. Retrovirus induced iPS cells (retro-iPS) were used as control. Some clones (\#2, 3, and 8) do not seem to have integration. 
Fig. 5 okita et al.

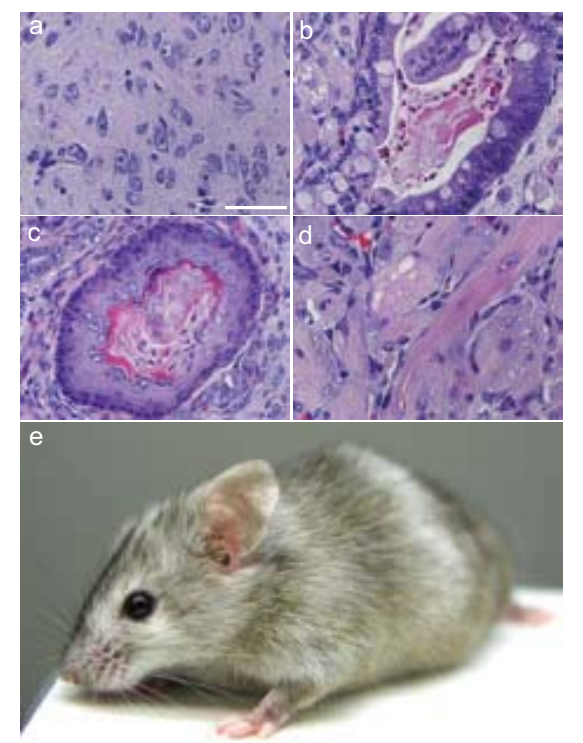

Figure 5 Pluripotency of plasmid-iPS cells.

Plasmid-iPS cells developed teratoma when subcutaneously transplanted into nude mice (a-d). Shown are hematoxylin \& eosin staining sections of neural tissue (a), gutlike epithelial tissue (b), epidermal tissue (c), and striated muscle (d). Bar indicates $50 \mu \mathrm{m}$. e. The iPS cells also contributed to chimeric mouse. iPS cells gave rise to gray hair. 